\title{
Ebola virus - from neglected threat to global emergency state
}

\author{
Daniela Alexandra de Meneses Rocha Aguiar Pacheco ${ }^{1 *}$, Acácio Agostinho Gonçalves Rodrigues ${ }^{2}$, Carmen Maria Lisboa da Silva ${ }^{3}$ \\ ${ }^{1} \mathrm{MSC}$ - Integrated Master Degree in Medicine, Universidade do Porto, Porto, Portugal \\ ${ }^{2}$ PhD - Director of the Department and Laboratory of Microbiology, Faculdade de Medicina, Universidade do Porto. MD, Department of Anesthesiology and Intensive Care, Burns Unit, Hospital de São João, Porto, Portugal \\ ${ }^{3}$ PhD - Professor of the Department and Laboratory of Microbiology, Faculdade de Medicina, Universidade do Porto. MD, Department of Dermatovenereology, Hospital São João, Porto, Portugal
}

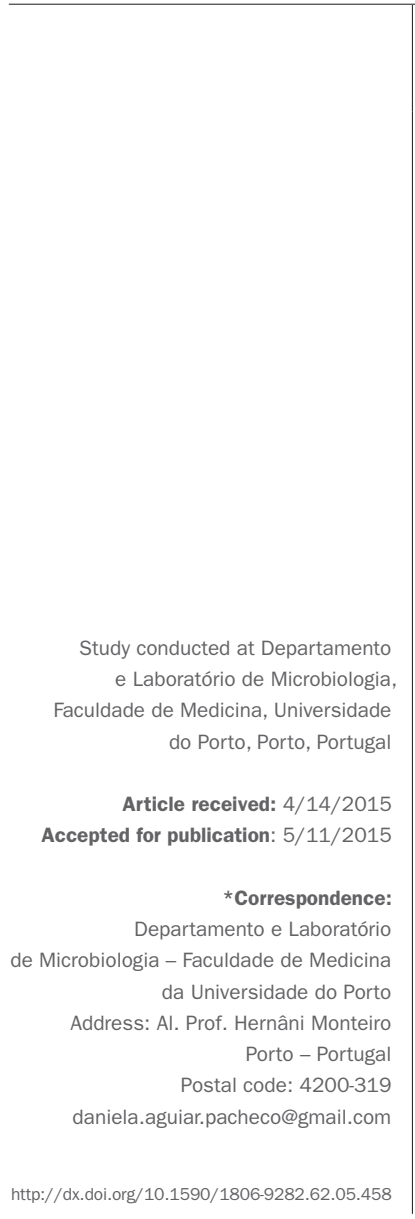

\section{SUMMARY}

Objective: This review aims to update knowledge about Ebola virus disease (EVD) and recent advances in its diagnosis, treatment and prevention.

Method: A literature review was performed using the following databases: ISI Web of Knowledge, PubMed, IRIS, Scopus and the websites of the CDC and the WHO. Additionally, we have included articles and reports referenced in the basic literature search, and news that were considered relevant.

Results: The Ebola virus, endemic in some parts of Africa, is responsible for a severe form of hemorrhagic fever in humans; bats are probably its natural reservoir. It is an extremely virulent virus and easily transmitted by bodily fluids. EVD's complex pathophysiology, characterized by immunosuppression as well as stimulation of an intense inflammatory response, results in a syndrome similar to septic shock. The diagnosis is difficult due to the initial symptoms that mimic other diseases. Despite the high mortality rates that can amount to $90 \%$, a prophylaxis (chemical or vaccine) or effective treatment does not exist. Two vaccines and experimental therapies are being developed for the prevention and treatment of EVD.

Conclusion: Although the virus is known for about 40 years, the lack of knowledge obtained and the disinterest of government authorities in the countries involved justify the state of emergency currently exists regarding this infectious agent. Only the coordination of multiple entities and the effective commitment of the international community will facilitate the control and effective prevention of EVD.

Keywords: Ebolavirus, epidemiology, pathology, therapeutics, neglected diseases.

\section{INTRODUCTION}

The Ebola virus causes Ebola virus disease (EVD), or simply Ebola, in humans and non-human primates (NHPs). ${ }^{1}$ Ebola is also known as hemorrhagic fever, a general term assigned to a group of serious illnesses associated with bleeding and caused by various viruses, including the Ebola virus. $^{2}$

It was first identified in 1976, during an outbreak in Zaire, ${ }^{3}$ and since then five species have been isolated: Zaire ebolavirus (ZEBOV), Sudan ebolavirus (SUDV), Bundibugyo ebolavirus (BDBV) Taï Forest ebolavirus (TAFV) and Reston ebolavirus (RESTV). The mortality rate of the Ebola virus ranges from 40 to $90 \%$, depending on the species. ${ }^{4}$

Since its discovery, certain sporadic outbreaks have occurred in Central Africa. However, since March 2014, the countries on the West African Coast (Guinea, Sierra Leone and Liberia) have undergone the largest and most severe outbreak of Ebola reported up to that time. ${ }^{5}$ On August 8, 2014 the World Health Organization (WHO) declared the outbreak in West Africa as a global public health emergency. ${ }^{6}$

The Ebola virus has an incubation period ranging between 2 and 21 days. Initially, the patient manifests signs and symptoms of flu that rapidly progress to bleeding, shock and multiple organ failure. ${ }^{5}$ Its pathophysiology is characterized by an intense inflammatory response, followed by immune system failure, and vascular and clotting alterations. ${ }^{5,7}$ Due to its high virulence, high mortality rate and ease of transmission via bodily fluids, the Ebola virus is regarded as a category A bioterrorism agent 
by the Centers for Disease Control and Prevention (CDC) and the National Institute of Allergy and Infectious Diseases (NIAID)..$^{8,9}$

There is no effective prophylactic protocol for Ebola. The available treatment can be summarized as palliative care, relief of symptoms and supportive measures. Some vaccines and drugs have been shown to be good candidates and appear to be promising in the future. Thus, prevention is essential and EVD must be reported to the National Notifiable Disease Surveillance System (NNDSS). The most efficient measures to control the spread of the disease involve isolation of infected individuals and medical procedures for containment, in order to prevent the infection of health care professionals. ${ }^{10,11}$

Despite four decades of documented existence of the virus and mortality rates that can rise to $90 \%$, there is still no effective treatment for Ebola, and the disease can be considered as a neglected tropical disease.

This review aims to contextualize outbreaks of Ebola, from its discovery up to the present time, describing the biology of the virus, updating knowledge about the pathophysiology of the disease and diagnostic methods, as well as listing current treatment options and prevention measures.

\section{Species of the Ebola virus}

The Ebola virus belongs to the family Filoviridae and genus Ebolavirus. The Ebola virus is classified into five species: Zaire ebolavirus (ZEBOV), Sudan ebolavirus (SUDV), Bundibugyo ebolavirus (BDBV), Taï Forest ebolavirus (TAFV), which come from Asia, and the Reston ebolavirus (RESTV), originated from Asia. The five species differ from each other in $40 \%$ of their amino acid sequence. ${ }^{1,4,7}$

All species originating from Africa cause EVD in humans and NHPs. ${ }^{12}$ The only species not originating from Africa, the Reston ebolavirus, was isolated for the first time in monkeys (Macaca fascicularis) imported from the Philippines to a quarantine unit in Reston, United States, in 1989. In 2008, it was reisolated from cynomolgus monkeys and, for the first time, in pigs from the Philippines. ${ }^{13,14}$ Anti-RESTV antibodies were detected in the serum of pig farmers in the Philippines, although not presenting clinical symptoms. So far, no case of EVD has been reported in humans. Nevertheless, the infection caused by RESTV can be fatal in cynomolgus monkeys and in rodents. ${ }^{14}$

Among EVD cases in humans, $90 \%$ are attributed to ZEBOV and SUDV. ZEBOV, SUDV and BDBV are responsible for outbreaks in humans with different mortality rates: from 80 to $90 \%, 40$ to $60 \%$, and $40 \%$, respectively.
In relation to TAFV, there is only one known case of infection in humans, although not fatal..$^{1,4,7}$

\section{ReView of Ebola outbreaks}

The virus was recognized for the first time near to the Ebola River, which crosses the region of Yambuku in Zaire, resulting in its name. ${ }^{3}$

The Ebola virus was identified in humans in 1976, corresponding to two different species, the Sudan ebolavirus (in Sudan) and the Zaire ebolavirus (in Zaire). ${ }^{3,15}$

In Sudan, it is believed that a worker was infected by an insectivorous bat, and the disease was disseminated by personal contact at hospitals in two cities. In Zaire, it is thought that the virus was contracted by a teacher from fresh antelope or monkey meat consumed a few weeks earlier. Similarly, dissemination in the population took place beginning at the city hospital. Later, in the 1990s, this virus arose related to the practice of funeral ceremonies and the hunting of NHPs. ${ }^{16,17}$

The third species of the virus, the Tai Forest ebolavirus, appeared in 1994 in Ivory Coast, after 15 years with no reported Ebola outbreaks. This virus was connected to the autopsy of a chimpanzee, with only a single case detected in a Swiss ethologist. ${ }^{13,16-18}$

In the chronology from its discovery until the 1990s (Figure 1), it can be noted that with the exception of a case of laboratory contamination in England and another in Russia, the outbreaks were mostly detected in the regions of Zaire/Democratic Republic of Congo (DRC), Sudan and Gabon. ${ }^{13,16-19}$ During this period, there were 703 deaths out of a total of 1,105 cases, corresponding to a mortality rate of approximately $64 \% .^{13}$

The fourth and final species of the virus in humans emerged in 2007 in Bundibugyo, Uganda, and was named according to this location. ${ }^{13,17}$

In the 2000s (Figure 1), with the exception of one case of laboratory contamination in Russia, only four countries were attacked by the virus - Uganda, the Republic of Congo, Gabon and Sudan, with 777 fatalities recorded out of a total of 1,253 cases ( $62 \%$ mortality rate). ${ }^{13,17}$

Since 2010, the countries most affected by the virus were once again Uganda and the Republic of Congo, with a total of 120 cases and 70 deaths (58.3\% mortality rate). ${ }^{13}$

The index case in the outbreaks is often not identified, but typically starts with one or a few cases of zoonotic transmission, which subsequently extends through intra-familiar transmission chains and is associated with health units (nosocomial). ${ }^{20,21}$

On March 23, 2014 the WHO announced a new Ebola outbreak, caused by the ZEBOV species. It began at 


\section{From discovery to the 1990 s}

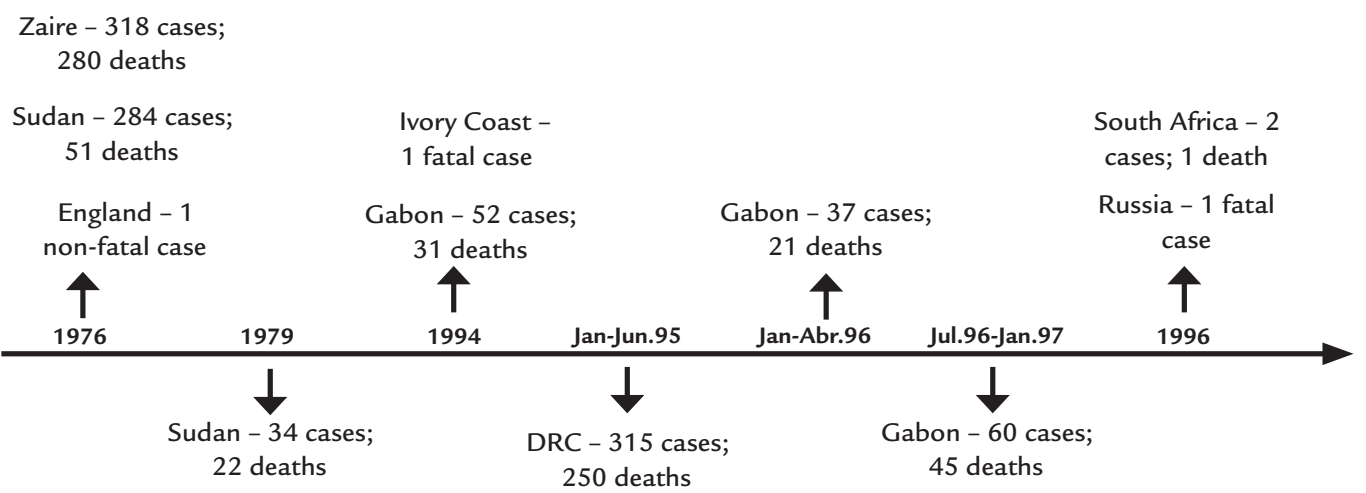

The 2000s

Rep. Congo - 35

cases; 29 deaths

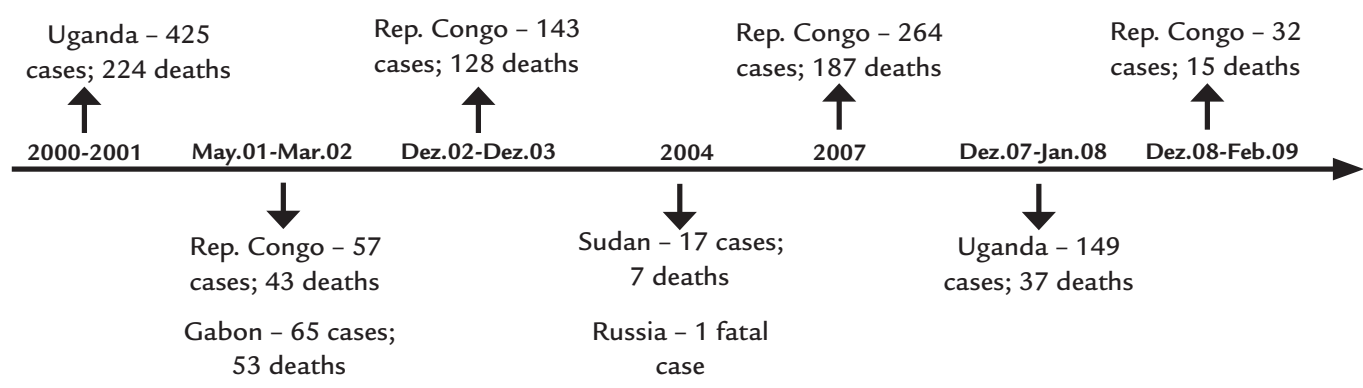

From 2010 to 2015

250 deaths 45 deaths

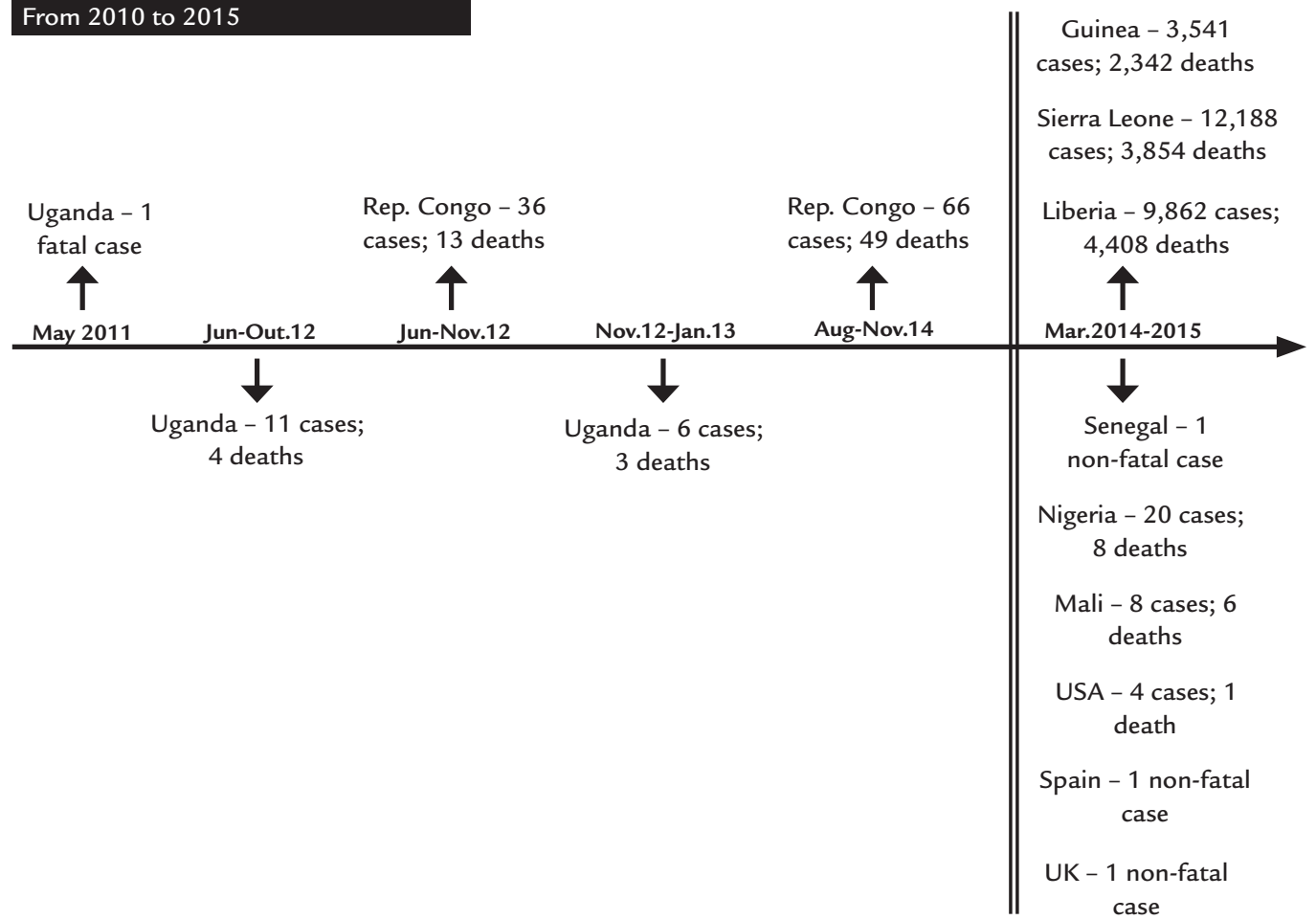

FIGURE 1 Chronology of Ebola outbreaks. Count of the total number of cases and deaths from Ebola.

DRC: Democratic Republic of Congo; Rep. Congo: Republic of the Congo; USA: United States of America.

Source: CDC. 2014 Ebola Outbreak in West Africa - Case Counts. ${ }^{23}$ 
the end of 2013 in the town of Gueckedou in the Republic of Guinea and spread very quickly to the urban centers of neighboring countries Liberia and Sierra Leone. ${ }^{5,22}$ Over a period of a few months, some sporadic cases were also diagnosed in Senegal, Nigeria, Mali, as well as in the United Kingdom, United States and Spain. Ebola outbreaks in these countries have officially ceased. ${ }^{23}$ In the current outbreak, the combined number of cases $(25,591)$ and deaths $(10,604)$ reported is greater than the total of all previous outbreaks. ${ }^{23}$

\section{RESERVOIR AND TRANSMISSION OF THE VIRUS}

There have been multiple studies in order to discover the natural reservoir of filoviruses. High titers of Ebola virus antibodies have been detected (by serology) in fruit bats and insectivorous bats. The fact that the bats can remain infected and are able to spread the virus without necessarily becoming sick suggests that they are the natural reservoir. This hypothesis is plausible because bats are often hunted and eaten in Africa. Studies with Marburgvirus also support this hypothesis. However, the route of transmission, from bats to humans and NHPs, and the factors that facilitate this process have not yet been sufficiently clarified. ${ }^{18,24,25}$

According to the WHO, the Ebola virus is a zoonosis transmitted by direct contact with the flesh or body fluids of the virus reservoir (fruit bat) and wild animals infected with the virus, which are found sick or dead in the forest. ${ }^{5}$ Airborne transmission among humans is thought not to be possible. This form of transmission of the virus is theoretically very unlikely. In fact, the rate of mutation since its discovery is constant and there is no significant evidence that it has become more contagious and more easily spread. To do so, the virus would need to undergo thousands of mutations over a long period of time. ${ }^{26} \mathrm{How}$ ever, it has been observed that pigs, whose infection primarily affects the respiratory tract, lethally infected NHPs without direct contact, suggesting a possible transmission of the virus via aerosols. ${ }^{4}$

ZEBOV has caused infection in domestic animals such as dogs and pigs, but without causing serious illness. Another potential danger of the virus is therefore revealed; the ability to infect domestic animals without causing disease, which could in the future become reservoirs and cause a new type of zoonotic transmission in humans. ${ }^{4,14}$

Transmission among humans occurs via direct contact (mucosal surfaces or abraded skin) with the blood, organs and bodily fluids of infected people or surfaces contaminated with these fluids. ${ }^{1,5,22}$ Transmission through intact skin is considered unlikely, but cannot be completely ruled out. ${ }^{1}$

\section{The Biology OF EBola VIRUS}

The Ebola virus is an $18.9 \mathrm{~kb}$ filamentous virus consisting of a negative-sense single strand RNA (ssRNA), with helical rearrangement. The genomic RNA encodes seven structural proteins: [major glycoprotein (GP), minor glycoprotein (VP30), matrix proteins (VP40 and VP24), nucleoprotein (NP), phosphoprotein VP35 and viral polymerase (L)] and two non-structural proteins [secreted glycoproteins (sGP) and small soluble glycoproteins (ssGP)]. The nucleocapsid consists of ssRNA, NP, VP35 and VP30 structural proteins and viral polymerase, forming the ribonucleoprotein complex (RNP), essential in viral transcription and replication. The VP40 and VP24 proteins establish bonds with the RNP and the inner surface of the viral envelope, respectively.,27,28 $\mathrm{NP}$ is the most abundant component of the nucleocapsid, with a close bond to the viral genome. It has been shown for the first time that NP is composed of two domains: one hydrophobic (N-terminal) and another hydrophilic (C-terminal). The C-terminal is an important antigenic determinant, with low conservation of the amino acid sequence among the five species of the Ebolavirus. ${ }^{28}$

Glycoprotein (GP) is dispersed on the surface of the viral envelope with a trimeric functional configuration. It is composed of GP1 (an extracellular protein) and GP2 (a protein anchored to the membrane) heterodimers connected by disulfide bridges. GP1 consists of a signal peptide, two outer glycosylated domains: the mucin-like domain and the glycan cap domain, overlying the receptor binding domain (RBD), protecting it from immunosuppressive action. The components of GP2 include fusion peptides, an N-terminal heptad repeat (NHR), a C-terminal heptad repeat (CHR) and a transmembrane domain (TM) ${ }^{10,29}$ The entry of filoviruses into the host cells involves three phases: cell adhesion, endocytosis and cell membrane fusion. GP plays an essential role in this entry. ${ }^{30} \mathrm{GP} 1$ is responsible for the connection to different host cell targets: C-type lectins (DC-SIGN, L-SIGN), TAM family receptor tyrosine kinases (Tyro3/Axl/Mer), $\alpha 5 \beta 1$ integrin and the $\mathrm{T}$ immunoglobulin mucin domain-1 (TIM-1) ${ }^{31}$ The virion undergoes endocytosis and is transported to mature endosomes where GP1 is cleaved through the action of endosomal proteases cathepsin $\mathrm{L}$ and $\mathrm{B}$, exposing the RBD. The RBD interacts with the endosomal receptor Niemann-Pick C1 (NPC1). ${ }^{31,32}$ It has been shown that the NPC1 is fundamental in the entry of filoviruses and seems to have an important role in the fusion be- 
tween the viral membrane and the membrane of the host cell. ${ }^{32}$ Next, GP2 fusion peptides are inserted in the endosomal membrane, forming hexamers between the NHR and $\mathrm{CHR}$, which induces membrane fusion. Afterwards, viral RNA and the RNP are released into the cytoplasm, where protein transcription, replication and translation take place. ${ }^{10,29,33}$

The main product of transcription of the GP gene is secreted glycoprotein (sGP), which is released in large quantities during infection by the five virus species and, thus, detected in the serum of hosts. The secreted glycoprotein is synthesized as a precursor protein (pre-sGP) which, after undergoing proteolytic cleavage by proteases such as furin, creates two monomers: sGP and a small $\Delta$-peptide. It is suggested that sGP participates in an antigenic subversion mechanism, where it functions as a decoy and thereby compromises the connection of circulating neutralizing antibodies to the GP surface glycoprotein. The $\Delta$-peptide, unlike the sGP, is retained in the cell for a long period before being released into the extracellular medium: it has been shown that in the extracellular medium it impedes the entry of filoviruses and prevents superinfection of cellular targets, although the mechanism is not yet clear. ${ }^{27,29}$

The phenomena of viral replication occur in the cytoplasm of the host cell, while the assembly and release of new viral particles take place in the cytoplasmic membrane. Matrix proteins VP24 and especially VP40, which has great affinity to the cell membranes, play a critical role in the assembly and release of the virus into host cell. ${ }^{10}$

VP40 is the virus's most abundant protein and in the absence of other constituent proteins of the virus it has the ability to produce virus-like particles (VLPs) in human cells, fully resembling the Ebola virion. ${ }^{34}$ The first crystal structure of VP40 suggests a monomer with two distinct domains important in the interaction with the plasma membrane. ${ }^{35}$ Recent studies suggest that VP40 is a dimer, with an N-terminal domain (NTD) that regulates dimerization and a C-terminal domain (CTD) that enables the connection to the membrane and oligomerization..$^{34}$ The connection to the plasma membrane causes a structural rearrangement in the VP40 protein: the dimers adopt a linear hexameric configuration. A third structure derived from VP40 is a ring-shaped octamer. The three structures have different functions in the virus' cell cycle: the dimers allow connection to the cell membrane, the hexameric structure participates in the assembly of the viral matrix and the octamer establishes bonds with the viral RNA, which are essential for the regulation of viral transcription. VP40 is a multi-functional protein playing various roles in the life cycle of the virus, which illustrates how a virus consisting of a small genome is able to assure different essential functions with a small number of proteins. The plasticity of VP40 makes it a good therapeutic target for developing antivirals. ${ }^{36}$

\section{Pathophysiology, clinical manifestations AND DIAGNOSIS}

The pathophysiology of Ebola is still not well understood because of the difficulty in conducting clinical studies under the conditions of outbreaks, meaning that a lot of information on the pathogenicity of the virus is obtained from laboratory tests. One of the common features of infection by filoviruses is the long time period between the initial cases of the disease and the identification of the agent, thus delaying the implementation of appropriate control measures. This results in the preservation of a person-person transmission chain in the community and in hospitals. ${ }^{21}$

Filoviruses penetrate the body through mucosa, skin abrasions or accidental injections. ${ }^{30}$ Several pathophysiological mechanisms explain how the infection caused by the Ebola virus causes severe hemorrhagic fever. On the one hand, GP glycoprotein and other viral matrix proteins have a direct toxic effect on the cells, destroying them. On the other, the interactions between the virus and the host's immune system contribute to its development. ${ }^{37}$ Antigen presenting cells (APCs) such as macrophages, monocytes and dendritic cells are the first cells to be infected by the virus. ${ }^{37,38}$ The virus replicates itself rapidly and new copies are released into the extracellular fluid. ${ }^{39}$ VP35 and VP24 proteins cause functional dysregulation of the APCs, preventing them from presenting antigens to naive T cells. VP35 and VP24 block the type I antiviral response of interferons (IFN). VP35 also causes inhibition of co-stimulatory molecules (CD4, CD80, CD86 and type II histocompatibility system) and the maturation of dendritic cells..$^{27,40}$ The loss of function of the APCs causes massive apoptosis of lymphocytes, although these are not infected by the virus. ${ }^{40}$ Simultaneously, the infected cells release large amounts of pro-inflammatory cytokines and chemokines, including interleukins IL- $1 \beta$, IL2, II-6, IL-10, tumor necrosis factor (TNF- $\alpha$ ), monocyte chemoattractant protein 1 (MCP-1) of macrophages and nitric oxide $(\mathrm{NO}){ }^{27}$ The systemic inflammatory response causes fever and the recruitment of more APCs to the site of infection; this results in the spread of infected cells to secondary lymphoid organs, lungs, liver, and other sites of viral replication. ${ }^{30,37,38}$ Hepatocellular necrosis reduces the synthesis of coagulation factors and plasma proteins 
which in conjunction with TNF- $\alpha$ synthesized by macrophages appears to explain the severe coagulation changes observed in Ebola infection. ${ }^{41}$ If the adrenal glands are affected, this causes sodium depletion, secondary hypotension and hypovolemia. It is not known whether dysfunction in the gastrointestinal tract (vomiting, diarrhea and bleeding) is the result of the direct effect of viral replication and/or circulating cytokines. Despite direct damage to organs, the severity of the disease is due to a large extent to the uncontrolled inflammatory response that causes an increase in vascular permeability, vasodilation and a loss of endothelial function. This results in multiorgan dysfunction and a syndrome similar to septic shock, which is ultimately fatal..$^{38,40}$

The incubation period of the Ebola virus ranges from 2 to 21 days, ${ }^{5}$ differing between the different species of the virus ${ }^{42}$ and also depending on the type of transmission ( 6 days for percutaneous transmission, 10 days for contact transmission). ${ }^{43}$ Asymptomatic individuals who are still in the incubation period are not contagious. However, symptomatic individuals hold the virus in the blood and other body fluids and the necessary isolation measures must be taken and health care professionals notified. ${ }^{44}$ Initially, patients manifest symptoms of flu such as fever, fatigue, headache, myalgia, and odynophagia. ${ }^{5}$ Later, multi-system impairment can be verified, with involvement of the gastrointestinal, respiratory systems, neurological and vascular systems. ${ }^{38,45}$ Hemorrhagic manifestations (petechiae, hematomas, bleeding in the mucous membranes and venipuncture sites, melena, hemoptysis) can be observed at the peak of disease. A diffuse, non-pruritic maculopapular rash may develop on the face, trunk and arms 5 to 7 days after the onset of symptoms, usually followed by desquamation in survivors. ${ }^{46,47}$ One challenge in the diagnosis of Ebola is the fact that it mimics other diseases such as malaria and typhoid fever, given its initial non-specific symptomatology. ${ }^{48}$ It is also difficult to distinguish between EVD and other hemorrhagic fevers endemic to the same regions. ${ }^{49}$ According to the CDC, a possible case of Ebola virus must be considered if the following two criteria are present: 1 - presence of fever or subjective sensation of such, or symptoms such as headache, asthenia, myalgia, vomiting, diarrhea, abdominal pain and unexplained bleeding; and 2 - presenting an epidemiological risk during the 21 days preceding the onset of symptoms. Epidemiological risk is understood, for example, as having traveled to a country undergoing rapid dissemination of the virus, having contact with a symptomatic Ebola patient or with animals infected with the virus. ${ }^{50,51}$ Ebola diagnostic confirma- tion involves the detection of viral RNA sequences via inverse polymerase chain reaction (RT-PCR) or enzymelinked immunosorbent assay (ELISA) in the blood and body fluids. The virus only reaches detectable levels in the blood 3 days after the onset of symptoms. The determination of IgM has low sensitivity for early diagnosis, but it is useful for monitoring the patient's immune response. ${ }^{52,53}$ These diagnostic tests require reference laboratories, trained personnel, and take from 12 to 24 hours, meaning it would be very important to have rapid tests for diagnosis. ${ }^{54}$ On February 19, 2015 the WHO approved the use of the ReEBOV ${ }^{\mathrm{TM}}$ Antigen Rapid Test Kit ${ }^{\circledR}$ (Corgenix Medical Corporation, Broomfield, USA) in countries affected by the Ebola virus. This is a test for qualitative detection of the ZEBOV VP40 antigen using immunochromatography, with results in 15 minutes. It has sensitivity of $92 \%$ in patients infected with the Zaire ebolavirus. ${ }^{55}$

The convalescence period is long and marked by asthenia, extensive desquamation of the skin and hair loss due to necrosis of the glands and other skin structures caused by the virus. ${ }^{56}$ During recovery, the formation of immune complexes is responsible for acute arthralgia. ${ }^{37}$ Patients remain infected while their blood and body fluids contain viral RNA. ${ }^{5}$ It is important to underline that the virus can persist in certain body fluids as the semen and breast milk, even after not being detectable in the blood. ${ }^{57,58}$

The immune response in patients infected with Ebola is not yet well characterized. Patients who survive usually improve in the second week after onset of the disease, ${ }^{39}$ while fatal cases are characterized by more severe early symptoms and signs that progress to multiple organ failure, typically dying in the second week. ${ }^{59,60}$ It has been shown that survivors of the infection had an IgM response 2 days after the appearance of symptoms and an IgG response 5 to 8 days after onset of symptoms. On the other hand, in fatal cases there seemed to be a lack of IgG response and only $30 \%$ of these patients developed IgM response..$^{59,61}$

\section{THERAPEUTIC MEASURES}

There is still no effective treatment for Ebola. Current treatment is merely supportive, involving measures to control fever, pain and secondary infections, as well as fluid therapy and treatment of kidney failure. ${ }^{10,11}$

Non-human primates are the standard animal model for the study of the virus and for therapeutic research in EVD. However, the ethical implications usually require conducting preliminary studies in small animals (immunodeficient mice, guinea pigs and hamsters model), with evidence of success. ${ }^{62}$ Nevertheless, due to the severity and 
magnitude of the current outbreak, the WHO has stated that the use of experimental drugs for the prevention and treatment of Ebola in humans is ethically permissible. ${ }^{63}$ Ongoing investigations within the scope of treatments for Ebola include ZMapp, TKM-Ebola, BCX-4430, antivirals (brincidofovir and favipiravir), plasma transfusions from survivors and phosphorodiamidate morpholino oligomer (POMs). ${ }^{11,62,64,65}$

ZMapp is a cocktail of monoclonal antibodies already used on victims of the current outbreak, but whose results have not yet been published. ${ }^{66}$ In NHPS, ZMapp was able to reverse the spread of the Ebola virus 5 days after exposure. ${ }^{67}$

TKM-Ebola is a new drug approved by the US Food Drug and Administration. It uses a small interfering RNA (si-RNA) technology that specifically affects three of the virus' proteins (VP24, VP35, L), reducing replication. ${ }^{68}$ From March to June 2015 phase II clinical trials took place in Sierra Leone. ${ }^{69,89}$

$\mathrm{BCX}-4430$ is a new nucleoside analog that indirectly inhibits RNA polymerase, blocking viral transcription and replication. It has shown effectiveness in mice and monkeys infected by Ebola virus and Marburg virus, respectively. ${ }^{70}$ Its use in NHPs obtained promising results, with a survival rate of $83 \%$ in monkeys infected with Ebola compared to the control group. ${ }^{71}$ From December 2014 to December 2015 it was underwent evaluation in phase I clinical trials. ${ }^{72,89}$

Two pre-existing antiviral drugs (brincidofovir and favipiravir) were approved by the WHO for use in the current outbreak. ${ }^{73}$ Brincidofovir showed in vitro activity against Ebola $^{74}$ and its administration in patients with EVD was reported in the United States of America. ${ }^{75} \mathrm{Fa}$ vipiravir has shown good results against Ebola in small animal models. ${ }^{76}$ In December, clinical trials with favipiravir began in Guinea. Since January, brincidofovir has been used at a treatment center in Monrovia, Liberia. ${ }^{77}$

Given the severity of the disease and the lack of effective treatments, there is a growing interest in the use of convalescent plasma therapy (CPT). During the 1995 outbreak in DRC, the survival of patients who had been administered CPT suggested that this type of passive immunization could bring benefits. ${ }^{56}$ Clinical trials on CPT were performed on Western Africa between November 2014 and November $2015 .^{89}$ If there is evidence of success, the survivors of the Ebola virus who do not contain viral RNA in body fluids could become donors of one liter of plasma every two weeks. ${ }^{78}$

PMOs are modified nucleic acid analogs that act in mRNA sequences, preventing viral transcription. AVI-7537 and AVI-7288 are under investigation. They have been shown to be protective in mice and guinea pigs in- fected with Ebola virus and Marburg virus ${ }^{65}$ and showed safety in humans in phase I studies. ${ }^{79}$

\section{Preventive measures}

Given that there is no specific treatment for Ebola, prevention is a crucial aspect to avoid the virus from spreading. Proper hand hygiene and avoiding contact with material or bodily fluids from people infected with Ebola are some of the measures. Health professionals should wear personal protective equipment and apply appropriate control measures and asepsis. ${ }^{80}$ There are also monitoring and tracking protocols for travelers from West African countries affected by Ebola. ${ }^{81}$ The current epidemic is responsible for wide dissemination of information about the disease and prevention measures in the media, hospitals, airports and other public institutions.

\section{VACCINES}

Outbreaks of EVD, although usually limited in terms of the number of cases and fatalities in comparison with other infectious diseases, often cause the closure of health units and the death of the clinical staff at such units, leading to a major impact on public health. In addition, Ebola is seen as a threat by society and as a bioterrorism agent. For these reasons, Ebola has become a good candidate for vaccination in risk areas. ${ }^{11}$

In the last decade we have seen the development of vaccines that have been shown to be protective in NHPs: recombinant adenoviruses, recombinant vesicular stomatitis virus, recombinant human parainfluenza viruses and virus-like particles. The future challenge involves conducting human clinical trials with these candidate vaccines, therefore, it is essential to understand the mechanism of action well and ensure their safety, especially in potentially immunocompromised populations. ${ }^{11}$

Currently, two candidate vaccines have received special attention: the Chimpanzee Adenovirus Serotype 3 (cAd3-EBO) produced by GlaxoSmithKline's with the collaboration of the United States National Institutes for Health and the Recombinant Vesicular Stomatitis Virus (rVSV-EBO) developed by the Public Health Agency of Canada. ${ }^{73}$ These are live attenuated vaccines that contain GP surface particles of ZEBOV that are not infectious. ${ }^{11}$

The cAd3-EBO demonstrated 100 and 50\% effectiveness against the Ebola virus 5 and 10 weeks after exposure, respectively, in cynomolgus monkeys. ${ }^{82}$ A single dose of rVSV-EBO provided complete protection against a lethal dose of ZEBOV in NHPs. ${ }^{83}$ The rVSV-EBO seems to confer protection through both intramuscular administration as well as orally. ${ }^{84}$ 
Considering the current global emergency, since September 2014 the two vaccines have been tested at an accelerated rate in various countries. On March 7, 2015 the first phase III clinical trial to evaluate the efficacy and effectiveness of the rVSV-EBOV vaccine began. The trial was concluded in February 2016. Guinea's vaccination (efficacy of 100\%) has shown that rVSV-EBO may be highly effective in preventing Ebola, under a ring vaccination strategy ${ }^{85,90}$ On January 2015 the first cAd3-EBO vaccine phase III clinical trial was begun in Liberia; during the following months it also underwent testing in neighboring countries affected by Ebola. ${ }^{86,91}$

\section{Conclusion}

Ebola virus is an endemic agent in certain regions of Africa that causes a severe hemorrhagic fever that is difficult to diagnose. These regions are targets of Ebola outbreaks due to cultural habits and the precariousness of the health system and sanitary and hygiene conditions. The consequences for public health and the economy of the regions affected are catastrophic. It is important to emphasize the severity of the disease and, in the absence of an effective treatment or vaccine, the education of the population in general and health professionals is essential for the prevention of infection. Globalization enables the emergence of infection elsewhere in the world.

There has been a growing interest in Ebola, especially after outbreaks of the disease in Zaire and Gabon in 1995 and 1996, respectively, and after reproduction of the film Outbreak, ${ }^{87}$ based on the book The Hot Zone, by Richard Preston. It was also featured in a documentary by the National Geographic Channel, ${ }^{88}$ which did justice to the threat the virus represents, being portrayed as a microscopic killer.

Despite having been identified 40 years ago, the essential aspects of the virus are still not completely clear to us, including transmission, laboratory diagnosis, pathophysiology, specific therapy and effective vaccination. The profound lack of interest shown by government and pharmaceutical organizations from developed countries, and the passivity of the WHO in relation to countries affected by the Ebola virus has led to the present situation of global threat, which surely won't stop here.

The fight against Ebola necessarily requires the global coordination of efforts between countries.

\section{Resumo}

Vírus ébola - de ameaça negligenciada ao estado de emergência global
Objetivo: esta revisão tem como objetivo atualizar os conhecimentos sobre a doença do vírus ébola (DVE) e sobre os recentes avanços nos métodos de diagnóstico, tratamento e prevenção.

Método: foi realizada uma revisão de literatura, utilizando as seguintes bases de dados: ISI Web of Knowledge, PubMed, IRIS, Scopus e os sites do Centers for Disease Control and Prevention (CDC) e da Organização Mundial da Saúde (OMS). Adicionalmente, foram incluídos artigos e relatórios referenciados na pesquisa bibliográfica de base e notícias consideradas relevantes.

Resultados: o vírus ébola, endêmico de algumas regiões da África, é responsável por uma forma grave de febre hemorrágica no homem, e os morcegos são provavelmente o seu reservatório natural. É um vírus extremamente virulento e de fácil transmissão pelos fluidos corporais. A complexa fisiopatologia da doença, caracterizada pela imunossupressão e pelo estímulo a uma intensa resposta inflamatória, resulta em uma síndrome semelhante ao choque séptico. O seu diagnóstico é difícil, por causa da sintomatologia inicial, que mimetiza outras doenças. Apesar das altas taxas de mortalidade, que podem alcançar os $90 \%$, não existe profilaxia (química ou vacinal) ou tratamento eficaz. Encontram-se em desenvolvimento duas vacinas e terapias experimentais para a prevenção e o tratamento da DVE.

Conclusão: apesar de ser um vírus conhecido há cerca de 40 anos, o escasso conhecimento obtido e o desinteresse das entidades governamentais de países envolvidos justificam o estado de emergência que se vive atualmente em relação a esse agente infeccioso. A coordenação por múltiplas entidades e o empenho efetivo da comunidade internacional facilitarão o seu controle e a prevenção eficaz.

Palavras-chave: Ebolavirus, epidemiologia, patologia, terapêutica, doenças negligenciadas.

\section{References}

1. Goeijenbier M, van Kampen JJ, Reusken CB, Koopmans MP, van Gorp EC Ebola virus disease: a review on epidemiology, symptoms, treatment and pathogenesis. Neth J Med. 2014; 72(9):442-8.

2. WHO. Haemorrhagic fevers, Viral [cited 2015]. Available from: http://www. who.int/topics/haemorrhagic_fevers_viral/en/.

3. WHO. Ebola haemorrhagic fever in Zaire, 1976. Bull World Health Organ. 1978; 56(2):271-93.

4. Ye L, Yang C. Development of vaccines for prevention of Ebola virus infection. Microbes Infect. 2015; 17(2):98-108.

5. WHO. Ebola virus disease [updated $2016 \mathrm{Jan}$ ]. Available from: http://www. who.int/mediacentre/factsheets/fs103/en/.

6. BBC. WHO: Ebola 'an international emergency' [updated 2014 Aug 8]. Available from: http://www.bbc.com/news/world-africa-28702356.

7. Menéndez JM, Simón F, Barberán J. [Ebola virus disease, an overview of the problem]. Rev Esp Quimioter. 2014; 27(4):230-8. 
8. Franz DR, Jahrling PB, Friedlander AM, McClain DJ, Hoover DL, Bryne WR, et al. Clinical recognition and management of patients exposed to biological warfare agents. JAMA. 1997; 278(5):399-411.

9. Rotz LD, Khan AS, Lillibridge SR, Ostroff SM, Hughes JM. Public health assessment of potential biological terrorism agents. Emerg Infect Dis. 2002; 8(2):225-30.

10. Li H, Ying T, Yu F, Lu L, Jiang S. Development of therapeutics for treatment of Ebola virus infection. Microbes Infect. 2015; 17(2):109-17.

11. Hoenen T, Groseth A, Feldmann H. Current ebola vaccines. Expert Opin Biol Ther. 2012; 12(7):859-72.

12. Dallatomasina S, Crestani R, Sylvester Squire J, Declerk H, Caleo GM, Wolz A, et al. Ebola outbreak in rural West Africa: epidemiology, clinical features and outcomes. Trop Med Int Health. 2015; 20(4):448-54.

13. CDC. Outbreaks chronology: Ebola virus disease [updated 2015 Mar 19]. Available from: http://www.cdc.gov/vhf/ebola/outbreaks/history/chronology. html.

14. Weingartl HM, Embury-Hyatt C, Nfon C, Leung A, Smith G, Kobinger G. Transmission of Ebola virus from pigs to non-human primates. Sci Rep. 2012; 2:811.

15. WHO. Ebola haemorrhagic fever in Sudan, 1976. Bull World Health Organ. 1978; 56(2):247-70.

16. Pourrut X, Kumulungui B, Wittmann T, Moussavou G, Délicat A, Yaba P, et al. The natural history of Ebola virus in Africa. Microbes Infect. 2005; 7(7-8):1005-14.

17. Muyembe-Tamfum JJ, Mulangu S, Masumu J, Kayembe JM, Kemp A, Paweska JT. Ebola virus outbreaks in Africa: past and present. Onderstepoort J Vet Res. 2012; 79(2):451.

18. Stein RA. What is Ebola? Int J Clin Pract. 2015; 69(1):49-58

19. Emond RT, Evans B, Bowen ET, Lloyd G. A case of Ebola virus infection. Br Med J. 1977; 2(6086):541-4

20. Francesconi P, Yoti Z, Declich S, Onek PA, Fabiani M, Olango J, et al. Ebola hemorrhagic fever transmission and risk factors of contacts, Uganda. Emerg Infect Dis. 2003; 9(11):1430-7.

21. MacNeil A, Farnon EC, Morgan OW, Gould P, Boehmer TK, Blaney DD, et al. Filovirus outbreak detection and surveillance: lessons from Bundibugyo. J Infect Dis. 2011; 204 Suppl 3:S761-7.

22. Kalra S, Kelkar D, Galwankar SC, Papadimos TJ, Stawicki SP, Arquilla B, et al. The emergence of ebola as a global health security threat: from 'lessons learned' to coordinated multilateral containment efforts. J Glob Infect Dis. 2014; 6(4):164-77.

23. CDC. 2014 Ebola Outbreak in West Africa - Case Counts [updated 2015 Mar 13]. Available from: http://www.cdc.gov/vhf/ebola/outbreaks/2014west-africa/case-counts.html.

24. Vogel G. Infectious disease. Genomes reveal start of Ebola outbreak. Science. 2014; 345(6200):989-90

25. Marí Saéz A, Weiss S, Nowak K, Lapeyre V, Zimmermann F, Düx A, et al. Investigating the zoonotic origin of the West African Ebola epidemic. EMBO Mol Med. 2015; 7(1):17-23.

26. CDC. Why Ebola is not likely to become airborne. 2015. Available from: http://www.cdc.gov/vhf/ebola/pdf/mutations.pdf.

27. Choi JH, Croyle MA. Emerging targets and novel approaches to Ebola virus prophylaxis and treatment. BioDrugs. 2013; 27(6):565-83

28. Dziuba囚ska PJ, Derewenda U, Ellena JF, Engel DA, Derewenda ZS. The structure of the C-terminal domain of the Zaire ebolavirus nucleoprotein. Acta Crystallogr D Biol Crystallogr. 2014; 70(Pt 9):2420-9

29. Lennemann NJ, Rhein BA, Ndungo E, Chandran K, Qiu X, Maury W. Comprehensive functional analysis of $\mathrm{N}$-linked glycans on Ebola virus GP1. mBio. 2014; 5(1):e00862-13.

30. Martines RB, Ng DL, Greer PW, Rollin PE, Zaki SR. Tissue and cellular tropism, pathology and pathogenesis of Ebola and Marburg viruses. J Pathol. 2015; 235(2):153-74.

31. Hofmann-Winkler H, Kaup F, Pöhlmann S. Host cell factors in filovirus entry: novel players, new insights. Viruses. 2012; 4(12):3336-62.

32. Miller EH, Chandran K. Filovirus entry into cells - new insights. Current Opin Virol. 2012; 2(2):206-14.

33. Harrison JS, Higgins CD, Chandran K, Lai JR. Designed protein mimics of the Ebola virus glycoprotein GP2 alpha-helical bundle: stability and $\mathrm{pH}$ effects. Protein Sci. 2011; 20(9):1587-96.

34. Adu-Gyamfi E, Soni SP, Jee CS, Digman MA, Gratton E, Stahelin RV. A loop region in the $\mathrm{N}$-terminal domain of Ebola virus VP40 is important in viral assembly, budding, and egress. Viruses. 2014; 6(10):3837-54
35. Dessen A, Volchkov V, Dolnik O, Klenk HD, Weissenhorn W. Crystal structure of the matrix protein VP40 from Ebola virus. EMBO J. 2000; 19(16):4228-36.

36. Bornholdt ZA, Noda T, Abelson DM, Halfmann P, Wood M, Kawaoka Y, et al. Structural rearrangement of ebola virus VP40 begets multiple functions in the virus life cycle. Cell. 2013; 154(4):763-74.

37. Mahanty S, Bray M. Pathogenesis of filoviral haemorrhagic fevers. Lancet Infect Dis. 2004; 4(8):487-98

38. Feldmann H, Geisbert TW. Ebola haemorrhagic fever. Lancet. 2011; 377(9768):849-62.

39. CDC. Ebola virus disease information for clinicians in U.S. healthcare settings 2015. Available from: http://www.cdc.gov/vhf/ebola/hcp/clinicianinformation-us-healthcare-settings.html.

40. Ansari AA. Clinical features and pathobiology of ebolavirus infection. J Autoimmun. 2014; 55:1-9.

41. Geisbert TW, Young HA, Jahrling PB, Davis KJ, Larsen T, Kagan E, et al. Pathogenesis of Ebola hemorrhagic fever in primate models: evidence that hemorrhage is not a direct effect of virus-induced cytolysis of endothelial cells. Am J Pathol. 2003; 163(6):2371-82.

42. Eichner M, Dowell SF, Firese N. Incubation period of ebola hemorrhagic virus subtype zaire. Osong Public Hand Res Perspect. 2011; 2(1):3-7.

43. WHO. Travel and transport risk assessment: Ebola. Interim guidance for public health authorities and the transport sector. 2014. Available from: http://www.who.int/csr/resources/publications/ebola/travel-guidance/en/.

44. Peters CJ, Jahrling PB, Khan AS. Patients infected with high-hazard viruses: scientific basis for infection control. Arch Virol Suppl. 1996; 11:141-68.

45. Hartman AL, Towner JS, Nichol ST. Ebola and marburg hemorrhagic fever Clin Lab Med. 2010; 30(1):161-77.

46. Bwaka MA, Bonnet MJ, Calain P, Colebunders R, De Roo A, Guimard Y, et al. Ebola hemorrhagic fever in Kikwit, Democratic Republic of the Congo: clinical observations in 103 patients. J Infect Dis. 1999; 179 Suppl 1:S1-7.

47. Kortepeter MG, Bausch DG, Bray M. Basic clinical and laboratory features of filoviral hemorrhagic fever. J Infect Dis. 2011; 204 Suppl 3:S810-6.

48. MacNeil A, Farnon EC, Wamala J, Okware S, Cannon DL, Reed Z, et al Proportion of deaths and clinical features in Bundibugyo Ebola virus infection, Uganda. Emerg Infect Dis. 2010; 16(12):1969-72.

49. CDC. Viral hemorrhagic fevers [updated 2013 Jun 19]. Available from: http:// www.cdc.gov/ncidod/dvrd/spb/mnpages/dispages/vhf.htm.

50. CDC. Case definition for Ebola virus disease (EVD) [updated 2014 Nov 16] Available from: http://www.cdc.gov/vhf/ebola/healthcare-us/evaluatingpatients/case-definition.html.

51. CDC. Epidemiologic risk factors to consider when evaluating a person for exposure to Ebola virus [updated 2014 Nov 28]. Available from: http://www. cdc.gov/vhf/ebola/exposure/risk-factors-when-evaluating-person-for-exposure. html.

52. CDC. Ebola virus disease: diagnosis [updated 2015 Apr 25]. Available from: http://www.cdc.gov/vhf/ebola/diagnosis/index.html.

53. Towner JS, Rollin PE, Bausch DG, Sanchez A, Crary SM, Vincent M, et al. Rapid diagnosis of Ebola hemorrhagic fever by reverse transcription-PCR in an outbreak setting and assessment of patient viral load as a predictor of outcome. J Virol. 2004; 78(8):4330-41

54. Leonard S. Containing Ebola: 7 next-gen rapid diagnostic tests [cited 2015 Mar 11]. Available from: http://www.mddionline.com/article/containingebola-7-next-gen-rapid-diagnostic-tests-11-07-14

55. WHO. First antigen rapid test for Ebola through emergency assessment and eligible for procurement [cited $2015 \mathrm{Feb}$ ]. Available from: http://www.who. int/medicines/ebola-treatment/1st_antigen_RT_Ebola/en/.

56. Rowe AK, Bertolli J, Khan AS, Mukunu R, Muyembe-Tamfum JJ, Bressler $\mathrm{D}$, et al. Clinical, virologic, and immunologic follow-up of convalescent Ebola hemorrhagic fever patients and their household contacts, Kikwit, Democratic Republic of the Congo. Commission de Lutte contre les Epidémies à Kikwit. J Infect Dis. 1999; 179 Suppl 1:S28-35.

57. CDC. Ebola virus disease: transmission [updated $2015 \mathrm{Jul} 22$ ]. Available from: http://www.cdc.gov/vhf/ebola/transmission/index.html.

58. WHO. What we know about transmission of the Ebola virus among humans [updated 2014 Oct 6]. Available from: http://www.who.int/mediacentre/ news/ebola/06-october-2014/en/.

59. Ksiazek TG, Rollin PE, Williams AJ, Bressler DS, Martin ML, Swanepoel R, et al. Clinical virology of Ebola hemorrhagic fever (EHF): virus, virus antigen, and IgG and IgM antibody findings among EHF patients in Kikwit, Democratic Republic of the Congo, 1995. J Infect Dis. 1999; 179 Suppl 1:S177-87. 
60. Sanchez A, Lukwiya M, Bausch D, Mahanty S, Sanchez AJ, Wagoner KD, et al. Analysis of human peripheral blood samples from fatal and nonfatal cases of Ebola (Sudan) hemorrhagic fever: cellular responses, virus load, and nitric oxide levels. J Virol. 2004; 78(19):10370-7.

61. Baize S, Leroy EM, Georges-Courbot MC, Capron M, Lansoud-Soukate J, Debre P, et al. Defective humoral responses and extensive intravascular apoptosis are associated with fatal outcome in Ebola virus-infected patients. Nat Med. 1999; 5(4):423-6.

62. Picazo E, Giordanetto F. Small molecule inhibitors of ebola virus infection. Drug Discov Today. 2015; 20(2):277-86.

63. WHO. Ethical considerations for use of unregistered interventions for Ebola virus disease (EVD) [updated 2014 Aug 12]. Available from: http://www.who. int/mediacentre/news/statements/2014/ebola-ethical-review-summary/en/.

64. Bishop BM. Potential and emerging treatment options for Ebola virus disease. The Ann Pharmacother. 2015; 49(2):196-206.

65. Iversen PL, Warren TK, Wells JB, Garza NL, Mourich DV, Welch LS, et al Discovery and early development of AVI-7537 and AVI-7288 for the treatment of Ebola virus and Marburg virus infections. Viruses. 2012; 4(11):2806-30.

66. Till B. DARPA may have a way to stop Ebola in its tracks [updated $2014 \mathrm{Sep}$ 9]. Available from: http://www.newrepublic.com/article/119376/ebola-drugzmapp-darpa-program-could-get-it-africa.

67. Qiu X, Wong G, Audet J, Bello A, Fernando L, Alimonti JB, et al. Reversion of advanced Ebola virus disease in nonhuman primates with ZMapp. Nature. 2014; 514(7520):47-53.

68. McCarthy M. FDA allows second experimental drug to be tested in Ebola patients. BMJ. 2014; 349:g5103.

69. WHO. New trial of TKM-Ebola treatment to start in Sierra Leone [updated 2015 Mar 12]. Available from: http://www.who.int/tdr/news/2015/trialTKM-ebola-trmnt/en/.

70. Warren TK, Wells J, Panchal RG, Stuthman KS, Garza NL, Van Tongeren SA, et al. Protection against filovirus diseases by a novel broad-spectrum nucleoside analogue BCX4430. Nature. 2014; 508(7496):402-5.

71. Inc. BP. BioCryst announces study results for BCX4430 in a non-human primate model of Ebola virus infection [updated $2014 \mathrm{Dec} 23$ ]. Available from: http://article.wn.com/view/2014/12/23/BioCryst_Announces_Study_ Results_for_BCX4430_in_a_NonHuman_P_x/.

72. ClinicalTrials.gov. A Phase 1 Study to evaluate the safety, tolerability and pharmacokinetics of BCX4430 [updated 2014 Dec 15]. Available from: https://clinicaltrials.gov/ct2/show/NCT02319772?term=bcx4430\&rank=1.

73. WHO. One year into the Ebola epidemic: a deadly, tenacious and unforgiving virus [updated 2015 Jan 15]. Available from: http://www.who.int/csr/disease/ ebola/one-year-report/introduction/en/.

74. Incorporation C. Chimerix's Brincidofovir has in vitro activity against Ebola [updated 2014 Sep 3]. Available from: http://ir.chimerix.com/releasedetail. cfm?releaseid $=868807$

75. Kroll D. Chimerix's Brincidofovir given To Dallas, Nebraska Ebola patients [updated 2014 Oct 7]. Available from: http://www.forbes.com/sites/ davidkroll/2014/10/07/chimerixs-brincidofovir-given-to-dallas-nebraskaebola-patients/.
76. Oestereich L, Lüdtke A, Wurr S, Rieger T, Muñoz-Fontela C, Günther S. Successful treatment of advanced Ebola virus infection with T-705 (favipiravir) in a small animal model. Antiviral Res. 2014; 105:17-21.

77. Caulderwood K. Chimerix Ebola drug Brincidofovir begins testing In Liberia [updated 2015 Jan 8]. Available from: http://www.ibtimes.com/chimerixebola-drug-brincidofovir-begins-testing-liberia-1777636.

78. Butler D. Ebola raises profile of blood-based therapy. Nature. 2015; 517(7532):9-10.

79. Heald AE, Iversen PL, Saoud JB, Sazani P, Charleston JS, Axtelle T, et al Safety and pharmacokinetic profiles of phosphorodiamidate morpholino oligomers with activity against ebola virus and marburg virus: results of two single-ascending-dose studies. Antimicrob Agents Chemother. 2014; 58(11):6639-47.

80. CDC. Ebola virus disease: prevention [updated 2015 Jul 22; cited 2015]. Available from: http://www.cdc.gov/vhf/ebola/prevention/index.html.

81. CDC. Fact Sheet: screening and monitoring travelers to prevent the spread of Ebola [updated 2015 Dec 29]. Available from: http://www.cdc.gov/vhf/ ebola/travelers/ebola-screening-factsheet.html.

82. Stanley DA, Honko AN, Asiedu C, Trefry JC, Lau-Kilby AW, Johnson JC, et al. Chimpanzee adenovirus vaccine generates acute and durable protective immunity against ebolavirus challenge. Nat Med. 2014; 20(10):1126-9.

83. Jones SM, Feldmann H, Ströher U, Geisbert JB, Fernando L, Grolla A, et al. Live attenuated recombinant vaccine protects nonhuman primates against Ebola and Marburg viruses. Nat Med. 2005; 11(7):786-90.

84. Qiu X, Fernando L, Alimonti JB, Melito PL, Feldmann F, Dick D, et al. Mucosal immunization of cynomolgus macaques with the VSVDeltaG/ ZEBOVGP vaccine stimulates strong ebola GP-specific immune responses. PLoS One. 2009; 4(5):e5547.

85. WHO. Ebola vaccine efficacy trial ready to launch in Guinea [updated 2015 Mar 5]. Available from: http://www.who.int/mediacentre/news/releases/2015/ ebola-vaccine-trial/en/.

86. GlaxoSmithKline's. Major milestone for GSK/NIH candidate Ebola vaccine as first doses shipped to Liberia for use in phase III clinical trial [updated 2015 Jan 23]. Available from: http://www.gsk.com/en-gb/media/pressreleases/2015/major-milestone-for-gsknih-candidate-ebola-vaccine-as-firstdoses-shipped-to-liberia-for-use-in-phase-iii-clinical-trial/.

87. Petersen W. Outbreak. USA: Warner Bros; 1995.

88. Sayenga K. MicroKillers- Ebola. USA: National Geographic Channel; 2005

89. WHO. Ebola R\&D: Landscape of clinical candidates and trials [cited 2015 Oct]. Available from: http://www.who.int/medicines/ebola-treatment/ EbolaR_D_public-report_oct2015.pdf.

90. Henao-Restrepo AM, Longini IM, Egger M, Dean NE, Edmunds WJ, Camacho A et al. Efficacy and effectiveness of an rVSV-vectored vaccine expressing Ebola surface glycoprotein: interim results from the Guinea ring vaccination cluster-randomised trial. The Lancet. 2015; 386(9996):857-66.

91. GlaxoSmithKline's. A new Ebola vaccine: the journay so far. Infographic. [cited 2015]. Available from: http://www.gsk.com/media/590199/ebolavaccine-journey-infographic.pdf. 